\title{
Reading the \\ South African transition
}

[ B O O K R E VIE W ]

Maré, Gerhard (2014) Declassified: Moving beyond the dead end of race in South Africa. Auckland Park (Johannesburg): Jacana. ISBN 978-1-4314-2020-9 pbk. Pages 200.

One of the most important temptations whilst reading an interesting and important text for the first time is imagining other ways in which the narrative could have been weaved together. Yet in a review, signals of outstanding themes and narrative brilliance such as those which I was happy to encounter in Gerhard Maré's, Declassified: Moving beyond the dead end of race in South Africa, are always a welcome reward in the course of a review such as the present one. This is my second review of an important book after several decades. Consequently, I am mindful of the fact that I should not play at reimagining a version of a text conceived and written by someone else. Undoubtedly, given the range and complexity of Maré's text, I would circumstances permitting, have preferred a second opportunity to study the text once more.

Maré's style and narrative pace in the early sections of the book is leisurely. One encounters an autobiographical thrust within the book's early introductory chapters which give the reader a wholesome encounter with the writer's development as an individual within his parents' home and the usual public institutions which are expected to prepare us for a productive adult existence namely, schools and universities. Needless to say, it was a typically white South African kind of apartheid era boyhood and early adulthood which the writer

\section{Chabani Manganyi}

University of Pretoria, Pretoria 
experienced. Significantly, in these early parts of the book, the narrative pace feels almost leisurely in both pace and content, features which sustain the autobiographical slant to it. However later on in the narrative, the reader discovers that the early pages and indeed chapters, are a kind of eye opener, an introduction to a wider vista of the writer's concerns especially about "moving beyond the dead end of race in South Africa", and his understanding of our country's transition from the century of South African apartheid to the current century of hope or hopelessness depending on one's view of the situation in our country today.

I need to emphasize the point that despite the relative brevity of this review, Mare's book is without doubt an important book on race and racism during the post-apartheid period in South Africa. Consider the chapter entitled " Thinking about race and our racial legacy". I found this chapter to be one of the outstanding chapters in Declassified. It is a tightly narrated account which deals with important public matters such as the central role of attributions, the notion that a black person is transparent in the course of black white encounters. Mare also makes the observation that in South Africa the everyday practice of racism and inequality have become banal. I interpreted the word banal to refer to commonplace happenings. And in one of what I consider to be his most pointed statements in his book, Maré asks:

"How deeply have these scars, structures and practices of that period of South African history remained in what has been attempted since 1994? Answers to these questions, if we can provide them, may give some content to the 'legacies' claimed for that period, and to an exploration of the manner in which they need to be addressed. Was the reflection undertaken during the transition period of the early 1990s thorough enough to allow South Africans to imagine achieving a truly post-apartheid country, and to gain the understanding needed for its realization? I would argue that this was not the case, and has not been so since 1994, leaving unanswered the question of how a truly post-apartheid South Africa should be envisaged." ( $p 35$ )

There is every reason to expect, as I did after reading the last sentence, that for Maré, the need to find some answers to the "question of how a truly post-apartheid South Africa should be envisaged", is a national imperative. Without doubt, I agree with him whole heartedly. Upon encountering the above statement, I made a note for my own benefit in which I said: "Here is one of the most important observations in Maré's book!"

As a reader, I was enthused by the above insight. In Mare's view, our country's African National Congress commandeered transition of the late 1990s and the beginning of the current century, the post-apartheid version of South Africa which was envisaged was a

PINS [Psychology in Society] 51 • 2016|110 
still born. I anticipated that in the prospective treatment likely to follow this profound observation, the sources of the failures, so extensively covered in a later section of Maré's text, would throw light on both the failures, their likely origins as well as the likely practical remedies. It is my belief that contained in his statement quoted above is a theme about an aborted transition. Looked at from the perspective of our history of longstanding expropriation of our country's land and other natural resources long after the arrival of Jan van Riebeeck on these shores in 1652, the South African transition which started in the 1990s remains one of the most significant events in our history and the history of race and racism in the world. It is my view that as illustrated in the quote above, Maré is, at his best, thoughtful, incisive and persuasive in his analysis and conclusions, a fact which is illustrated as stated earlier, in some chapters of his book.

However, the chapter entitled, "Fair discrimination" was to me, the most challenging section of an interesting and important text. My notes to myself on this chapter are detailed, reflecting the questions which came to mind. Overall, the writing and analysis reflected in this part of the text lack the tight rigour of earlier sections of the book referred to earlier on! For example, some readers will be struck, as I was by the implied suggestion that there were no constructive policies and laws in the work initiated by the Government of National Unity as well as the Mandela and Mbeki administrations which had real significance for public life at the turn of the last century and present day South Africa. Is it not the case that the South African transition was commandeered by leaders of both the African National Congress, the National Party and other smaller parties? Indirectly, it was also commandeered by hordes of Inkatha Freedom Party conflict mongers in the streets of Johannesburg and elsewhere during the 1990s. As a reader I found myself asking the question: is it conceivable that there were no positive, constructive policies and laws impacting upon race and racism which are direct products of the transition under presidents Mandela and Mbeki?

I find it difficult to think meaningfully about 1994 and subsequent years of the mid to late 1990 s South Africa without recognizing the complexity of the transition and its formidable challenges. I believe that studies of our transition beginning in the 1990s until now, need to acknowledge the burden of both the past we want to leave behind, and the new future we envisage. It is worth remembering that the post 1994 "failure" if that is how we should regard it, is not unique. Think about the longstanding race dilemma of African Americans in the United States, the biggest democracy in the world! Think also about the history and early promise of African states rising from the bonds of colonialism. Could it be that there is an African National Congress problem and no white problem in the kind of South Africa which the mid to late nineteen nineties has left us? No former National Party residue? The author's primary focus on the African National Congress's preoccupation with race and its reported failure to confront and dislodge it in our country's public 
life make it appear as if white South Africans played no notable role in our country's transition and the state of our country at the present time. Mare's analysis in the closing chapters is eloquent yet the probability is high that because of this enthusiasm, little or hardly any visible attention is given to the inevitability of the transition scenario as we have created and experienced it. Finally, the implied assumption that the Mandela administration and for that matter even the Mbeki administration had a completely free hand while race based inequality in the country remained largely unchecked as is still the case today, undermines the indisputable complexity of the late 20th century transition in our country. 